\title{
Zinc Finger Protein Neuro-D4
}

National Cancer Institute

\section{Source}

National Cancer Institute. Zinc Finger Protein Neuro-D4. NCI Thesaurus. Code C157306.

Zinc finger protein neuro-d4 (380 aa, $\sim 43 \mathrm{kDa}$ ) is encoded by the human DPF1 gene. This protein is involved in neuronal dendrite growth and cell survival. 